\title{
What Drives Choice of Coping Strategies Against Ex-Post Weather and Climate Shocks Among Smallholder Fish Farmers in Malawi?
}

\author{
Griffin E. Masoambeta Miracle* Julius H. Mangisoni Davies H. Ng'ong'ola \\ Lilongwe University of Agriculture and Natural Resources, P.O Box 219, Lilongwe, Malawi
}

The research was funded by the Aquaculture Centre of Excellence (ACE II) project.

Abstract

The study was conducted in Dowa and Mchinji districts of central Malawi to understand how fish farmers make choice of village savings and loans, income generating activities and insurance to deal with weather and climate shocks. A multivariate probit model was used to analyse the drivers of farmers' choice so that we know if the strategies are complements or substitutes. Data from 353 fish farmers was collected. The study has shown that education level, age of the farmer, farming experience and the hypothetical insurance bid are significant drivers of fish farmers' choice. We recommend promotion of adult literacy, civic education and enhancement of extension services on the coping strategies as a proxy to formal education which has proved so crucial in the adoption of coping strategies.

Keywords: fish farmers, weather and climate shocks, coping strategies, multivariate probit model

DOI: $10.7176 / \mathrm{JESD} / 10-4-02$

\subsection{Introduction}

Weather and climate shocks have emerged to be serious threats to the agricultural sector in many different parts of the world (Shannon and Motha, 2015). In Malawi, these shocks include extreme temperatures, dry spells within a rainfall season that turn into a drought if they last for more than three months (Chabvunguma et.al., 2015), and excess precipitation which results in floods and of course, pest and diseases (Shannon and Motha, 2015). In Dowa and Mchinji Districts, households face challenges in food production due to persistent dry spell, pest and disease and other associated factors (FEWSNET, 2015). To the detriment of fish production, fish farmers in the study area, practice a low input, low output form of aquaculture relying heavily on the interaction with the ecosystem and naturally available feed to support their fish (Omonepade, 2014), which can hardly suffice the changing climate and weather. Further, many fish farmers are withdrawing from the enterprise due to drying up of the ponds as smallholder fish farmers cannot invest much to maintain water flows in their ponds. Therefore, an understanding of how farmers in general and fish farmers in particular make their choices to cope with the changing climate will be an important ingredient to any efforts to lessen the burden of weather and climate shocks.

\subsection{Coping to weather and climate shocks}

Literature stalwartly suggests that in recent times adverse and extreme weather events such as floods, droughts, and dry spells have increased in incidence, intensity and extent, exacerbating rural poverty and threatening the sustainability of rural livelihoods (Mulwa et al., 2017). For example, as highlighted by Zulu (2017), Malawi's agriculture sector is most vulnerable to climate shocks, particularly droughts and floods which threatens food security, a third of Malawi's agro-driven Gross National Product (GNP), a major share of exports value, and the livelihoods of $85 \%$ of Malawi's predominantly rural and densely distributed 17 million people. The study noted that a larger number of the population constitutes poor farmers subsisting on less than \$1 USD a day and dependent on low-input, low output rain-fed agriculture, and small landholdings which limits their Climate Change (CC) adaptation options and capacity.

In a bid to understand coping to weather and climate shocks, Iheke and Agodike (2016) analysed the factors that influences adoption of climate change mitigating measures by smallholder fish farmers in Imo State of Nigeria. The probit regression exhibited that the significant variables influencing adoption of climate change mitigation measures were age of the farmer, farming experience, tenancy status, years of education, extension contact, income, access to credit and membership of farmers' association.

Further, Berman et.al (2014) investigated what drives household coping strategies in rural Uganda under various climatic hazards knowing that rural households in sub-Saharan Africa of which Malawi is part of, draw on various coping strategies to reduce the impact of climatic hazards on their livelihoods. Using empirical data from Uganda, the research found that households' coping strategy relies on household characteristics and livelihood activity and that these coping strategies vary depending on the hazard. It was thus concluded that coping strategy is found to be hazard specific for households that lack market-orientated activities, whereas those with market access rely on economic activities regardless of hazard. It was therefore recommended that to maintain and improve the livelihoods and coping strategies of the most vulnerable to climatic variability and change, policies that 
advocate diversification away from a sole reliance on customary activities need to recognize the level and opportunity for market-based activities. In addition, these interventions must consider different sensitivities to different hazards as well as community homogeneity in order to effectively support rural communities to cope with climate variability.

Uddin et al. (2014) in their study on the drivers of households coping strategies towards environmental degradation and climate change used logit model to identify the socio-economic factors affecting the farmers' adoption of adaptive strategies. The results showed that almost all households perceived that climate is changing and the key drivers to their choice of adaptive strategy towards climate change was the social economic status of the households under consideration. Further the adaptation strategies that were hinted among others include crop diversification, integrated farming system, crop insurance and use of irrigation farming.

Against this backdrop of hastily varying weather conditions and the severity of the impact on poor fish farmers, it is urgent that the various options available to smallholder fish farmers to cope are documented. A thorough understanding of farmers' choice of coping strategies is critical for the success of any efforts to mitigate the negative effects of weather and climate shocks on fish farmers' well-being. As argued by Berman et.al, (2014), better understanding of farmers coping process will enable more targeted interventions and policy formulations. This being the case, we investigated what drives fish farmers' choice of coping strategies against weather and climate shocks. We examined the factors affecting choice of coping strategies to deal with weather and climate shocks.

The findings of this study are crucial in informing the design and implementation of strategies to curb the negative repercussions of climate change on fish farmers' well-being. Further, the analysis of fish farmers' choice of coping strategies contributes on information as to how differences in socio economic characteristics affect their choices.

\subsection{Approaches to modelling coping and adapting to climate change and variability}

Some studies have used univariate analysis on adaptation studies in Malawi and elsewhere. For example, Zulu et.al, (2017) used univariate probit to analyze the determinants of individual households' coping strategies to weather and climate shocks. Farid et.al (2015) used multiple regression approach to examine the extent of adoption of improved farm practices by the farmers of Northern Bangladesh and determined the influencing factors for adopting these practices. Further, Montle and Teweldemedhin (2014) applied a multinormial logit to determine the factors affecting farmers' levels of strategy diversification in the face of climate shocks in Namibia. A departure in terms of the approach is Mulwa et.al (2017) who used a multivariate probit approach to model how farmers in Malawi respond to climate risks. The latter approach is more realistic considering that farmers use a multiple options to deal with shocks. Using the same econometric method the study contributes to the literature by using both the pond level (farm level) and household level data to analyse drivers of farmers' choice of coping strategies to deal with weather and climate shocks in the context of smallholder fish farmers in Malawi. To the best of our knowledge, no study has been done in Malawi that specifically target fish farmers' coping to weather and climate shocks. Many studies on climate change adaptation have focused on crop production other than specifically fish production.

\subsection{Theoretical framework}

The study established a theoretical framework following a random utility theoretical structure. Random Utility Model (RUM) defines a choice resolution of which an individual $i$ has a set of substitute coping strategies $j$ from which to select (McFadden, 1978). It is presumed that each coping alternative has its specific qualities which influence individual's choice. RUM aids us address fish farmers' choices over alternative coping strategies (us Saqib, 2004). This model is grounded on that an individual originates utility by selecting a number of alternatives. The utilities $U_{i}$ are latent variables, and the noticeable preference indicators manifest the essential utilities (us Saqib, 2004).

Following Uddin et.al (2017) the utility $U_{i j}$ that an individual $i$ derives from selecting strategy $\mathrm{J}$, from a choice set (C) of alternatives can be described as follows:

$U_{i j}=V_{i j}(Z, q)+\psi_{i j}$

In equation (2.1), $\mathrm{q}$ is a vector of characteristics of each coping strategy $j(j=1,2, \ldots, J)$ as selected by an individuali. $\mathrm{Z}$ is a vector of household specific characteristics. $\psi_{i j}$ is the error term.

An individual $i$ jointly selects coping strategy $\mathrm{j}$ from a set of alternative strategies. A strategy is assumed to be selected from an overall set of strategies only if and if only the expected utility $U_{i 2}$ is more than the actual utility $U_{i 1}$ of all other bundle of coping strategies (C) (Uddin et.al, 2017).

\subsection{Methodology}

Using face to face interviews, household level data was collected on 353 fish farming household heads in Dowa and Mchinji Districts of central Malawi. The data included household socioeconomic characteristics, pond 
characteristics, household's perception on climate and weather shocks, and households' coping strategies against weather and climate shocks. A multi-stage sampling method was applied to select the 353 households. Firstly, a purposive or judgment sampling technique was used to select the Traditional Authorities (TAs) with high probability of getting fish farmers in Mchinji and Dowa. Then, sections from each selected TA were also selected purposively in order to make sure that the sections with more fish farmers are captured. Finally, probability proportional sampling method was used to select villages to sample our farmers.

\subsection{Model specification and estimation strategy}

We followed a Multivariate Probit Model (MVP) approach as opposed to the univariate modelling. The multivariate probit approach concurrently models the effect of a set of explanatory variables on each different coping strategies and at the same time allowing for the possible relationship between unobserved disturbances, as well as the association among the adoptions of diverse strategies (Mulwa et.al, 2017). The equation in a system of multiple coping choices can be shown as

$U_{i j}=X_{i j} B_{j}+\varepsilon_{i j}(j=1,2,3, \ldots, s)$

And the observable dichotomous choice variables are;

$U_{i j}=\left\{\begin{array}{c}1 \text { if } U_{i j} \geq 0 \\ 0 \text { other wise }\end{array}(j=1,2,3, \ldots, s)\right.$

Where $U_{i j}$ is the utility that the fish farmer $i$ gets by choosing strategy $j$ from the given set of options.

In the MVP model where the adoption of several coping strategies is possible, the error terms jointly follow a multivariate normal distribution (MVN) with zero conditional mean and variance normalized to unity (Kpadonou, et al., 2016). $\operatorname{MVN}(0, \Omega)$ and the symmetric covariance matrix $\Omega$ is given by

$$
\Omega=\left[\begin{array}{cccc}
1 & \rho_{12} & \cdots & \rho_{1 J} \\
\rho_{21} & 1 & & \rho_{2 J} \\
\vdots & \vdots & \ddots & \\
\rho_{J 1} & \rho_{J 2} & \cdots & 1
\end{array}\right]
$$

In the equation (4.3) above, $\rho\left(\begin{array}{ll}r & o\end{array}\right)$ is the pairwise correlation coefficient between the error terms. Kpadonou, et al., (2016), state that, the sign and the significance of the correlation coefficient, $\rho$, provide evidence on the nature of the relationships between adoption equations i.e. a complementarity for a positive sign and substitutability for a negative sign. The multivariate probit estimator allows the covariance between the error terms to be correlated across strategies but not across observations within a given practice as shown in equation below (Marenya \& Barrett, 2007).

$E\left(\varepsilon_{t j} \varepsilon_{s j}\right)=0 \forall$ strategies $s \neq t$ for individual $j$ but $E\left(\varepsilon_{t j} \varepsilon_{t k}\right)=\rho j k \forall j \neq k$

\subsection{Dependent Variables}

Being a multivariate approach, the study had three coping strategies namely village savings and loans (VSLs), rainfall indexed insurance (RII) and other income generating activities (OIGAs) of which fish farmers choose from. These choices were also the dependent variables. The strategies were chosen in line with the literature on adaption to ex-post weather and climate shocks, augmented by the focus group discussions with the selected fish farmers per district.

\subsection{Independent Variables}

The study incorporated explanatory variables based on the review of the available literature on farmers' adaptation to weather and climate related shocks and the availability of the variables in the data set. The variables were mainly on socio-economic characteristics of the fish farmers (age of household head, household size, marital status, farmer education, and years of farming). Since the study is on aquaculture, the study also pays special attention to pond size, fingering expenses, feed expenses, fish sales and operational status ${ }^{1}$.

The data shows that fish farming in Dowa and Mchinji is dominated by male headed households (78\%) and the average age, years of education and years of farming of the household heads were 43.78 years, 6.21 years and 5 years respectively. Further, the average household size in the sampled households was 6 with over $49 \%$ of the households having 6 to 9 members. The mean annual income for the sample was MK221035.2 (US\$291.71). There was however, high variation in income across the sampled farmers as evidenced by high standard deviation than the overall mean and median incomes. Furthermore, income is positively skewed ${ }^{2}$ (skewed to the right) meaning that the majority of the households have their incomes below the mean income (Nicholson and Snyder, 2008). The

\footnotetext{
${ }^{1}$ Operational status refers to the situation of being either a full time fish farmer or a part time fish farmer.

${ }^{2}$ Skewness is when data points cluster more toward one side of the scale than the other or the right and left side of the distribution are shaped differently from each other.
} 
data also reveals that during the 2017 stocking season ${ }^{1}, 27.48 \%$ of the farmers in the entire sample had pond sizes in the range of 201-500 $\mathrm{M}^{2}$ with the average being $1108 \mathrm{M}^{2}$. In terms of expenditure on fingerings, $71.67 \%$ of the sampled households spent in the range of between MK0 to MK50000 and on average, the farmers spent MK8060.057 (US\$10.75). Overall, an average of MK9085.27 (US\$12.11) was spent on feeds. The average net fish sales for the farmers was MK35019.55 (US\$46.69). Over 61\% of the farmers were full time farmers.

\subsection{Results and Discussions}

\subsection{Drivers of Fish Farmers' Choice of Coping Strategies against Weather and Climate Shocks \\ 5.2.1 Diagnostic tests}

A correlation matrix was developed which showed weak correlations between independent variables. This shows that multicollinearity was not a serious problem in the model. Furthermore, the Multivariate test for normality (mvtest with normality sub-option), was used in stata to test for normality and the results show that the errors of the fitted variables were normally distributed at the $1 \%$ level. Endogeneity was tested as proposed by Hausman (1978). Endogeneity makes identification of causal effect difficult because of biased estimates (Katengeza et.al, 2018). The possible sources of endogeneity in this study could be reverse causality. To control for endogeneity, the study used the control function approach as hinted by Katengeza et.al (2018). In the control function, each of the endogenous variables (bid price, income and operating status) was used to generate a new variable called a proxy variable (predicted variable) and it is these predicted variables that were used in the final model instead of the original endogenous variables. The idea behind the control function correction is to derive a proxy variable that influences the dependent variable and is dependent on the error term (Petrin \& Train, 2009). The proxy variable makes sure that the variation in the endogenous variable be independent of the error and standard estimation approaches will again be consistent. The approach is used in the absence of proper instrumental variables of the endogenous variables

\subsubsection{Farmers' choice of coping strategies}

Tables 5.1, 5.2 and 5.3 summarizes the drivers of farmers' choice of coping strategies. Being a multivariate probit model, the results were interpreted based on the fact that each choice had its own drivers in the overall and district disaggregated models.

Table 5.1: Multivariate probit model results on choice of coping strategies in Dowa and Mchinji Districts

\begin{tabular}{|c|c|c|c|c|c|c|}
\hline \multirow[t]{2}{*}{ Variable name } & \multicolumn{2}{|c|}{$\operatorname{Pr}(\mathrm{CCS}==\mathrm{WTJ})=0.6324$} & \multicolumn{2}{|c|}{$\operatorname{Pr}(\mathrm{CCS}==\mathrm{OIGA})=0.2275$} & \multicolumn{2}{|c|}{$\operatorname{Pr}(\mathrm{CCS}==\mathrm{VSL})=0.1401$} \\
\hline & $\begin{array}{l}\text { Marginal } \\
\text { Effects }\end{array}$ & p-value & $\begin{array}{l}\text { Marginal } \\
\text { Effects }\end{array}$ & $\mathrm{p}$-value & $\begin{array}{l}\text { Marginal } \\
\text { Effects }\end{array}$ & p-value \\
\hline Inincome (MK) & $\begin{array}{l}-0.018 \\
(0.048)\end{array}$ & 0.703 & - & - & $\begin{array}{l}-0.074 \\
(0.036)\end{array}$ & 0.357 \\
\hline Marital status ( $1=$ Married, $0=$ single) & $\begin{array}{l}-0.204^{*} \\
(0.117)\end{array}$ & 0.084 & $\begin{array}{l}0.107 \\
(0.109)\end{array}$ & 0.324 & $\begin{array}{l}-0.147 \\
(0.104)\end{array}$ & 0.157 \\
\hline Inpond value (MK) & $\begin{array}{l}0.121 \\
(0.108)\end{array}$ & 0.259 & - & - & $\begin{array}{l}0.057 \\
(0.080)\end{array}$ & 0.480 \\
\hline Shock experience $(\mathrm{l}=$ Yes, $0=$ No) & $\begin{array}{l}0.801 * * * \\
(0.252)\end{array}$ & 0.001 & $\begin{array}{l}0.404^{*} \\
(0 . .237)\end{array}$ & 0.103 & - & - \\
\hline Years of farming (Years) & $\begin{array}{l}0.077 \text { * } \\
(0.036)\end{array}$ & 0.059 & - & - & - & - \\
\hline Years of education & $\begin{array}{l}0.077 * * \\
(0.035)\end{array}$ & 0.026 & - & - & - & - \\
\hline Operating status ( $\mathrm{l}=$ fulltime $0=$ part-time) & $\begin{array}{l}-0.634^{* * *} \\
(0.256)\end{array}$ & 0.013 & $\begin{array}{l}0.299 * \\
(0.167)\end{array}$ & 0.073 & - & - \\
\hline Bid price $1\left(\mathbf{M K} / \mathbf{M}^{2}\right)$ & $\begin{array}{l}1.250^{* * * *} \\
(0.3231)\end{array}$ & 0.000 & - & - & - & - \\
\hline Bid price $2\left(\mathbf{M K} / \mathbf{M}^{2}\right)$ & $\begin{array}{l}1.064^{* * *} \\
(0.291)\end{array}$ & 0.000 & - & - & $\begin{array}{l}0.131 \\
(0.174)\end{array}$ & 0.454 \\
\hline Age of the household head (Years) & $\begin{array}{l}-0.009 \\
(0.008)\end{array}$ & 0.295 & - & - & - & - \\
\hline Gender household head ( $1=$ Male, $0=$ Female $)$ & - & - & $\begin{array}{l}0.385^{\star} \\
(0.210)\end{array}$ & 0.067 & - & - \\
\hline Household size (Number) & - & - & $\begin{array}{l}0.100^{* * *} \\
(0.039)\end{array}$ & 0.010 & $\begin{array}{l}0.081^{* *} \\
(0.037)\end{array}$ & 0.028 \\
\hline Farm coping strategies $(\mathrm{l}=\mathrm{Yes}, 0=\mathrm{No})$ & - & - & $\begin{array}{l}0.039 * * * \\
(0.007)\end{array}$ & 0.000 & - & - \\
\hline Infeeds expense (MK) & - & - & $\begin{array}{l}-0.193^{* *} \\
(0.089)\end{array}$ & $\begin{array}{l}0.030 \\
(0.065)\end{array}$ & $\begin{array}{l}0.099 \\
(0.065)\end{array}$ & 0.129 \\
\hline Fish sales (MK) & - & - & - & - & $\begin{array}{l}-0.126^{*} \\
(0.071)\end{array}$ & 0.078 \\
\hline Value of worst damage (MK) & - & - & - & - & $\begin{array}{l}-0.175^{* * *} \\
(0.067)\end{array}$ & 0.008 \\
\hline
\end{tabular}

*** Significant at 1 percent level; ** significant at 5 percent level; * significant at 10 percent significant level. Log likelihood $=-379.72201 \quad$ Number of observations $=294 \quad$ LR $\operatorname{ch} 2(30)=107.48 \quad$ Prob $>\operatorname{chi} 2=0.0000$

\footnotetext{
${ }^{1}$ A period from the time baby fish (fingerings) are put in the pond up to harvest. This can take a minimum of 5 months up to 8 months or above depending on weather and climate and the type of fish raised.
} 
Table 5.2: Multivariate probit model results on choice of coping strategies in Dowa District

\begin{tabular}{|c|c|c|c|c|c|c|}
\hline \multirow[t]{2}{*}{ Variable name } & \multicolumn{2}{|c|}{$\operatorname{Pr}(\mathrm{CCS}==W T J)=0.6324$} & \multicolumn{2}{|c|}{$\operatorname{Pr}(\mathrm{CCS}=\mathrm{OIGA})=0.2275$} & \multicolumn{2}{|c|}{$\operatorname{Pr}(\mathrm{CCS}==\mathrm{VSL})=0.1401$} \\
\hline & $\begin{array}{l}\text { Marginal } \\
\text { Effects }\end{array}$ & p-value & $\begin{array}{l}\text { Marginal } \\
\text { Effects }\end{array}$ & p-value & $\begin{array}{l}\text { Marginal } \\
\text { Effects }\end{array}$ & p-value \\
\hline Inincome (MK) & $\begin{array}{l}-0.074 \\
(0.070)\end{array}$ & 0.288 & - & - & $\begin{array}{l}-0.018 \\
(0.062)\end{array}$ & 0.765 \\
\hline Marital status ( $1=$ Married, $0=$ single $)$ & $\begin{array}{l}-0.421^{* *} \\
(0.205)\end{array}$ & 0.040 & $\begin{array}{l}-0.0001 \\
(0 . .171)\end{array}$ & 0.999 & $\begin{array}{l}0.014 \\
(0.212)\end{array}$ & 0.944 \\
\hline Inpond value (MK) & $\begin{array}{l}0.077 \\
(0.166)\end{array}$ & 0.644 & - & - & $\begin{array}{l}0.233 \\
(0.152)\end{array}$ & 0.124 \\
\hline Shock experience $(1=$ Yes, $0=$ No $)$ & $\begin{array}{l}0.594^{*} \\
(0.370)\end{array}$ & 0.104 & $\begin{array}{l}0.162 \\
(0 . .299)\end{array}$ & 0.587 & - & - \\
\hline Years of farming (Years) & $\begin{array}{l}0.032 \\
(0.045)\end{array}$ & 0.482 & - & - & - & - \\
\hline Years of education & $\begin{array}{l}0.057 \\
(0.055)\end{array}$ & 0.293 & - & - & - & - \\
\hline Operating status ( $1=$ fulltime $0=$ part-time) & $\begin{array}{l}-1.048^{* \star * \pi} \\
(0.404)\end{array}$ & 0.009 & $\begin{array}{l}-0.547 * * \\
(0.250)\end{array}$ & 0.029 & - & - \\
\hline Bid price $1\left(\mathbf{M K} / \mathbf{M}^{2}\right)$ & $\begin{array}{l}1.003^{* *} \\
(0.481)\end{array}$ & 0.037 & - & - & - & - \\
\hline Bid price $2\left(\mathbf{M K} / \mathbf{M}^{2}\right)$ & $\begin{array}{l}1.838 * * * \\
(0.560)\end{array}$ & 0.001 & - & - & $\begin{array}{l}-0.186^{* *} \\
(0.334)\end{array}$ & 0.030 \\
\hline Age of the household head (Years) & $\begin{array}{l}-0.021^{*} \\
(0.012)\end{array}$ & 0.085 & - & - & - & - \\
\hline Gender household head ( $1=$ Male, $0=$ Female $)$ & - & - & $\begin{array}{l}-0.529 * \\
(0.342)\end{array}$ & 0.102 & - & - \\
\hline Household size (Number) & - & - & $\begin{array}{l}0.135^{* *} \\
(0.061)\end{array}$ & 0.027 & $\begin{array}{l}0.299 * * * \\
(0.083)\end{array}$ & 0.000 \\
\hline Farm coping strategies $(1=$ Yes, $0=\mathrm{No})$ & - & - & $\begin{array}{l}0.027^{* * *} \\
(0.011)\end{array}$ & 0.010 & - & - \\
\hline Infeeds expense (MK) & - & - & $\begin{array}{l}-0.089 \\
(0.170)\end{array}$ & 0.598 & $\begin{array}{l}0.082 \\
(0.137)\end{array}$ & 0.543 \\
\hline Fish sales (MK) & - & - & - & - & $\begin{array}{l}-.032 \\
(0.137)\end{array}$ & 0.812 \\
\hline InValue of worst damage (MK) & - & - & - & - & $\begin{array}{l}-0.194^{*} \\
(0.124)\end{array}$ & 0.101 \\
\hline
\end{tabular}

*** Significant at $1 \%$ level; ** significant at $5 \%$ level; * significant at $10 \%$ level

Log likelihood $=-158.50301 \quad$ Number of observations $=132 \quad$ LR $\operatorname{ch} 2(30)=61.51 \quad$ Prob $>\operatorname{ch} 2=0.0002$

Table 5.3: Multivariate probit model results on choice of coping strategies in Mchinji District

\begin{tabular}{|c|c|c|c|c|c|c|}
\hline \multirow[t]{2}{*}{ Variable name } & \multicolumn{2}{|c|}{$\operatorname{Pr}(\mathrm{CCS}==\mathrm{WTJ})=0.6324$} & \multicolumn{2}{|c|}{$\operatorname{Pr}(\mathrm{CCS}=\mathrm{OIGA})=0.2275$} & \multicolumn{2}{|c|}{$\operatorname{Pr}(\mathrm{CCS}==\mathrm{VSL})=0.1401$} \\
\hline & $\begin{array}{l}\text { Marginal } \\
\text { Effects }\end{array}$ & p-value & $\begin{array}{l}\text { Marginal } \\
\text { Effects }\end{array}$ & p-value & $\begin{array}{l}\text { Marginal } \\
\text { Effects }\end{array}$ & p-value \\
\hline Inincome (MK) & $\begin{array}{l}0.042 \\
(0.077)\end{array}$ & 0.588 & - & - & $\begin{array}{l}0.038 \\
(0.048)\end{array}$ & 0.430 \\
\hline Marital status ( $1=$ Married, $0=$ single) & $\begin{array}{l}-0.210 \\
(0.181)\end{array}$ & 0.244 & $\begin{array}{l}\overline{0.297 * *} \\
(0.109)\end{array}$ & $\overline{0.061}$ & $\begin{array}{l}-0.268^{+*} \\
(0.129)\end{array}$ & 0.038 \\
\hline Inpond value (MK) & $\begin{array}{l}0.184 \\
(0.182)\end{array}$ & 0.309 & - & - & $\begin{array}{l}-0.016 \\
(0.102)\end{array}$ & 0.872 \\
\hline Shock experience $(1=$ Yes, $0=$ No) & $\begin{array}{l}1.203^{* * *} \\
(0.433)\end{array}$ & 0.005 & $\begin{array}{l}0.821^{\circ} \\
(0.237)\end{array}$ & 0.062 & - & - \\
\hline Years of farming (Years) & $\begin{array}{l}0.191 * * \\
(0.037)\end{array}$ & 0.021 & - & - & - & - \\
\hline Years of education & $\begin{array}{l}0.100^{*} \\
(0.060)\end{array}$ & 0.095 & - & - & - & - \\
\hline Operating status ( $1=$ fulltime $0=$ part-time) & $\begin{array}{l}-0.865 \\
(0.544)\end{array}$ & 0.112 & $\begin{array}{l}-0.099 \\
(0.167)\end{array}$ & 0.719 & - & - \\
\hline Bid price $1\left(\mathrm{MK} / \mathrm{M}^{2}\right)$ & $\begin{array}{l}1.456^{\circ * *} \\
(0.559)\end{array}$ & 0.009 & - & - & - & - \\
\hline Bid price $2\left(\mathrm{MK} / \mathrm{M}^{2}\right)$ & $\begin{array}{l}0.982^{* *} \\
(0.486)\end{array}$ & 0.043 & - & - & $\begin{array}{l}-0.186 \\
(0.236)\end{array}$ & 0.429 \\
\hline Age of the household head (Years) & $\begin{array}{l}0.009 \\
(0.014)\end{array}$ & 0.539 & - & - & - & 0.132 \\
\hline Gender household head ( $1=$ Male, $0=$ Female) & - & - & $\begin{array}{l}1.261^{* * *} \\
(0.210)\end{array}$ & 0.000 & - & - \\
\hline Household size (Number) & - & - & $\begin{array}{l}0.075 \\
(0.039)\end{array}$ & 0.179 & $\begin{array}{l}0.028 \\
(0.044)\end{array}$ & 0.522 \\
\hline Farm coping strategies ( $1=$ Yes, $0=$ No) & - & - & $\begin{array}{l}0.061^{* * *} \\
(0.007)\end{array}$ & 0.000 & - & - \\
\hline Infeeds expense (MK) & - & - & $\begin{array}{l}-0.243^{+} \\
(0.089)\end{array}$ & 0.025 & $\begin{array}{l}0.084 \\
(0.081)\end{array}$ & 0.300 \\
\hline Fish sales (MK) & - & - & - & - & $\begin{array}{l}-0.150^{*} \\
(0.091)\end{array}$ & 0.099 \\
\hline InValue of worst damage (MK) & - & - & - & - & $\begin{array}{l}-0.204^{+*} \\
(0.087)\end{array}$ & 0.020 \\
\hline
\end{tabular}

*** Significant at 1 percent level; ** significant at 5 percent level; * significant at 10 percent significant level Log likelihood $=-190.27626$

Number of observations $=162$

LR $\operatorname{ch} 2((30)=60.49$

Prob $>$ ch $2=0.0008$ 


\subsubsection{Rainfall Indexed Insurance (RII)}

\subsection{Effects of years of schooling on the choice of RII}

Table 5.1 shows that years of schooling positively and significantly influenced the choice of insurance at the $5 \%$ level. A one year increase in education level increases the probability of adopting insurance by $0.077(7.7 \%)$. This is probably because education enables farmers to have access to new information and ideas, and therefore capacitating them to develop a more understanding on the importance of insurance against weather and climate shocks. These results concur with Berman et.al. (2014) and Asgary etal. (2004) who also found a positive relationship between education level and choice of coping strategies against shocks in western Uganda and rural Iran, respectively. The disaggregated model shows that education has a positive and significant influence at the $10 \%$ level on adoption of insurance in Mchinji District (Table 5.3), but could not significantly explain the adoption of insurance in Dowa District (Table 5.2).

\subsection{Effects of bid price on choice of RII}

Table 5.1 shows that farmers who said yes to a given bid of the premium ${ }^{1}$ had a probability of adopting insurance by $125.1 \%$ for the first bid and $106.4 \%$ for the second bid. The findings concur with Trang (2013) who found a positive and significant relationship between the bid value and adoption of insurance in a study on the determinants of rice farmers' willingness to pay for area indexed insurance in Vietnam. Across districts, Tables 5.2 and 5.3 reveal that bid price had an influence on choice of insurance in both Dowa and Mchinji. Table 5.2 shows that acceptance of the bid prices by farmers in Dowa raised the probability of adopting insurance by $100.3 \%$ for the first bid and $183.8 \%$ for the second bid. In Mchinji, acceptance of the bid prices raised the probability of choosing insurance by $145.6 \%$ for the first bid and $98.2 \%$ for the third bid (Table 5.3).

\subsection{Effects of number of years of farming on choice of RII}

Table 5.1 shows that number of years of farming had a significant influence on the adoption of insurance in the aggregate model at the $10 \%$ level of significance. A one year increase in the years of farming raised the probability of adopting by $7.7 \%$. However, the disaggregated model in Table 5.3 reveals that the number of years of farming significantly raised the probability of adopting insurance in Mchinji District at the 5\% level. A one year increase in the number of years of farming increased the probability of choosing insurance by $19.1 \%$. This could be the case because being in the fish farming business for more years as was the case with Mchinji, meant that the farmers had more years of exposure to weather and climate shocks and their impacts. Such farmers are likely to develop a skill(s) to deal with such shocks, in form of participating in an insurance scheme or otherwise. The findings are similar to those of Iheke and Agodike (2016) who noted that years of farming may give an indication of the practical knowledge a farmer has acquired on how to overcome certain inherent farm production problems, some of which are effects of climate change.

\subsection{Effects of age of the farmer on choice of RII}

Generally, age of the farmer significantly influenced farmers' choice of coping insurance against weather and climate shocks in the aggregate model at the $10 \%$ level. A one year increase in the age of the farmer reduces the probability of adopting insurance by $2.1 \%$. This may be because most farmers in the study area are old and are probably risk averse ${ }^{2}$ to the operations of insurance. They have lived in the area for many years and accumulated some experience pertaining to operation of insurance. Mulwa et.al. 2017 argued that older farmers with experience easily understand coping strategies and this may also explain why age of the farmer negatively influences adoption of insurance in fish farming.

\subsection{Effects of operational status on choice of RII}

Operational status of the farmer, which is the state of either being a full-time fish farmer or a part-time fish farmer, affected choice of insurance at the $1 \%$ level (Table 5.1). In the overall model, Table 5.1 further shows that being a full-time farmer reduced the probability of choosing insurance by $63.4 \%$ than being a part-time farmer. These results concur with Iheke \& Agodike (2016) who noted that being a full-time farmer gives one a chance to understand inherent problems on one's farm more easily than when one is a part time farmer. This explains why full-time farmers in Dowa and Mchinji had a low chance of joining insurance than part-time farmers (Tables 5.2 and 5.3). In Dowa, being a full-time farmer reduced the probability of adopting insurance by $105 \%$ more than being a part-time farmer (Table 5.2). Operation status could not significantly affect the adoption of RII in Mchinji District (Table 5.3).

\subsection{Effects of shock experience on choice of RII}

In the overall past shock experience significantly influenced the choice of insurance at the $1 \%$ level (Table 5.1). Previous shock experience by the farmer raised the probability of adopting insurance by $80.1 \%$. The disaggregated models reveal that shock experience significantly influenced choice of insurance at the $10 \%$ and $1 \%$ levels for Dowa and Mchinji respectively. In Dowa, previous shock experience raised the probability of adopting insurance

\footnotetext{
${ }^{1}$ An agreed amount of money that the farmer is supposed to pay to the insurance company as a price for joining the insurance scheme. In the case of the rainfall indexed insurance, the premium is decided by the amount that is chargeable per square meter and the total pond size.

${ }^{2} \mathrm{~A}$ person is risk averse when he/she avoid getting involved into risk behaviours that may make them lose something as a result of their involvement.
} 
by $59.4 \%$ and in Mchinji, previous shock experience raised the probability of adopting insurance by $120.3 \%$. Similar results were reported by Ghazanfar et.al. (2015).

\subsection{Effects of marital status of choice of RII}

Marital status of the household significantly influenced the choice of insurance at the $10 \%$ (Table 5.1). Being married reduces the probability of adopting insurance by $20.4 \%$. However, the disaggregated models reveal that marital status significantly influenced the choice of insurance in Dowa District at the 5\% level. Being married reduced the probability of choosing insurance as a coping strategy to weather and climate shocks by $42.1 \%$. The observed results conform to the fact that married people may have more responsibilities and due to such, most may be resource constrained. Thus strategies that require initial/ upfront capital are likely to side line more married than unmarried people (2014: Namwata et al., 2010).

\subsubsection{Village Savings and Loans (VSLs)}

\subsection{Effects of the bid price on choice of VSLs}

Table 5.1 shows that the bid values had no significant effect on village savings and loans (VSLs).The disaggregated models shows that acceptance of the second bid price reduced the probability of adopting VSL by $18.6 \%$ in Dowa (Table 5.2). This could be the case because the insurance would act as a substitute to the use of VSLs in coping to weather and climate shocks as would both require funds to finance them.

\subsection{Effects of fish sales on choice of VSLs}

Fish sales of the farmers influenced the choice of VSL as a coping mechanism to weather and climate shocks. In the overall model, fish sales affected choice of VSL at the $10 \%$ level (Table 5.1). A one percent increase in fish sales reduced the probability of choosing VSL by $12.6 \%$. The observed results are in line with the fact that luck of enough income is a key driver for joining village savings and loans (McIntosh et al., 2013). Furthermore, the increased fish revenue capitates the farmers to concentrate much on the enterprise than other sources of income. The disaggregated models did not show any significant influence of income on the choice of village savings and loans.

\subsection{Effects of the household size on choice of VSLs}

In the overall model, household size significantly influenced the choice of VSL at the $5 \%$ level of significance (Table 5.1). A one member increase in the household affected choice of VSL by $8.1 \%$. The observed results are due to the fact that increased members would require extra income for survival which VSL could provide. The disaggregated models show that household size had a significant influence at the $1 \%$ level in Dowa District. In Dowa, a one member increase in the household size increased the probability of choosing VSL by $29.9 \%$.

\subsection{Effects of value of worst damage on choice of VSL}

Overall, Table 5.1 shows that value of the worst damage the farmer ever experienced significantly affected choice of VSL at the $1 \%$ level of significance. A percentage increase in the value of previous damages on fish production reduced the probability of adopting VSL by $17.5 \%$. In Dowa, Table 5.2 shows that a one percentage increase in value of worst damages reduced the likelihood of joining VSL by $19.4 \%$ and in Mchinji, a one percent increase in the value of the worst damage reduced the likelihood of joining VSL by $20.4 \%$. The findings are in line with Trang (2013); Mulwa et.al (2017); Ghazanfar et.al (2015) who noted that the value of damage a farmer ever experienced may determine the range of future choices of coping strategies in the future.

\subsubsection{Other Income Generating Activities (OIGAs)}

\subsection{Effects of the household size on choice of OIGAs}

Household size influenced the choice of OIGAs at the $1 \%$ level of significance. Overall, a one member increase in the household size raised the probability of adopting OIGAs by $10 \%$. This observation may be due to that household size is crucial when it comes to household activities (Hassen et.al. 2012). The disaggregated models shows a significant effect of household size on the choice of OIGAs in Dowa District at the 5\% level. A member increase in the household size increases the probability of adopting OIGAs by $13.5 \%$.

\subsection{Effects of operational status on choice of OIGAs}

In the overall model, operational status significantly influenced the choice of OIGAs at the $10 \%$ level. Being a fulltime fish farmer reduced the probability of choosing OIGA by $29.9 \%$ (Table 5.1). In Dowa, operation status negatively influenced the choice of OIGAs at the 5\% level (Table 5.2). Being a fulltime farmer reduced the probability of choosing OIGAs by $54.7 \%$ than being a part-time farmer. These results can be attributed to the fact that a full time fish farmer devotes a lot of time in the management of fish and has little time available for other activities (Iheke \& Agodike, 2016).

\subsection{Effects of gender of the household head on choice of OIGAs}

Gender significantly affected the choice of OIGA as a coping strategy to weather and climate shocks. In the overall model, gender significantly influenced the choice of OIGA at the 10\% level (Table 5.1). Being male raised the probability of choosing OIGA by $38.5 \%$. The observed results conform to the fact that women are resource constrained. Thus strategies that require initial/ upfront capital are likely to side line more women than men (Abdullah et al., 2014: Namwata et al., 2010).

Across districts, gender had a significant positive influence on the choice of OIGA Mchinji District at the $1 \%$ level 
(Tables 5.3). Being male raised the probability of choosing OIGA by $126.1 \%$ (Table 5.3).

4.5.2.3.4 Effects of shock experience on choice of OIGA

In the overall model, Table 5.1 shows that shock experience by the fish farmers influenced the choice of OIGA at the $10 \%$ level of significance. Past shock experience increased the probability of choosing OIGA by $1 \%$. This observation can be attributed to the fact farmers who experienced some shocks before are capacitated to prepare for eventualities and may diversify their income sources through say, OIGA (Ghazanfar et.al, 2015).

Across districts, the disaggregated models in Tables 5.2 and 5.3 show that past shock experience only significantly explained the choice of OIGA in Mchinji District at the $10 \%$ level of significance. Shock experience increased the probability of choosing OIGA as a coping strategy among fish farmers by $82.1 \%$.

\subsection{Effects of farm coping strategies on choice of OIGA}

Generally, the availability of other farm coping strategies than RII, VSL and OIGA significantly affected the choice of OIGA at the $1 \%$ level (Table 5.1). Availability of other coping strategies on the farm increases the probability of choosing OIGA by $3.9 \%$. The observed result may be attributed to the fact that other strategies may need some start-up capital of which OIGAs like small-scale businesses can provide. The disaggregated models shows significant effect of farm coping strategies in both Dowa and Mchinji at the $1 \%$ level of significance. In Dowa, availability of other coping strategies raised the probability of choosing OIGA by $2.7 \%$. In Mchinji, availability of other coping strategies raised the probability of choosing OIGA by $6.1 \%$.

\subsection{Effects of feeds expenses on choice of OIGA}

Generally, feed expenses influenced the choice of OIGA at the 5\% level of significance in both Dowa and Mchinji Districts (Table 5.1). A percentage increase in the expenses on feeds reduces the probability of choosing OIGA by $19.3 \%$. This may be due to increased pressure on the money resources the farmer may be endowed with (McIntosh et.al, 2010). In Mchinji, feed expenses influenced the choice of OIGA at the 5\% level of significance. A percentage increase in the cost of feeds reduced the probability of choosing OIGA by $24.3 \%$. No significant effect was observed in Dowa.

\subsection{The Rho Matrix of the coping strategies}

Table 4.17 shows a significant and negative relationship at the $1 \%$ level among the three dependent variables which are also the coping strategies namely: village savings and loans (VSLs), other income generating activities (OIGAs) and insurance (RII). This implies that these coping strategies can be used as substitutes in order for fish farmers to deal with the weather and climate shocks they face.

\subsection{The Rho Matrix of the coping strategies}

Table 5.4 shows a significant and negative relationship at the $1 \%$ level among the three dependent variables which are also the coping strategies namely: village savings and loans (VSLs), other income generating activities (OIGAs) and insurance (RII). This implies that these coping strategies can be used as substitutes in order for fish farmers to deal with the weather and climate shocks they face.

Table 5.2.2: Rho matrix of the coping strategies for Dowa and Mchinji Districts

\begin{tabular}{|c|c|c|c|}
\hline Variable & VSL & OIGA & Insurance \\
\hline$\rho V S L$ & 1 & & \\
\hline pOIGA & $-0.128(.1364)^{* * *}$ & 1 & \\
\hline oInsurance & $-0.073(.1347)^{* * *}$ & $-.027(.1035)^{* * *}$ & 1 \\
\hline
\end{tabular}

$* * *$ Means significant at $1 \%$ level, $p<0.01$

Likelihood ratio test of rho $21=$ rho $31=\mathrm{rho}=0$

Chi2(3) $=8.14709$ Prob $>$ chi2 $=0.004$

Notes: Standard errors in parentheses

\subsection{Conclusions and policy recommendations}

The multivariate probit results indicated that education level, operating status, years of farming experience, age of the farmer, shock experience, marital status and bid price are significant drivers of the adoption of RII. Bid price, fish sales, household size and value of worst damage were very crucial in the adoption of VSLs in both districts. Finally, household size, operating status, gender of the household head, shock experience, availability of other farm coping strategies and feeds expenses were key in the adoption of OIGAs. Our study therefore concludes that years of schooling, bid price, operational status, gender, cost of feeds, farm coping strategies, fish sales, marital status, shock experience, age of the farmer, years of farming experience and value of worst damages are important drivers of choice of coping strategies against weather and climate shocks. We recommend promotion of adult literacy and civic education on weather and climate related issues which may also be part of enhancing extension services. The policy and program intervention should consider training lead farmers who may in turn train fellow farmers on how to deal with weather and climate related issues. These trainings should be extended to new fish farmers to enhance their preparedness in handling weather and climate shocks. 


\section{References}

Asgary, A., Willis, K., Taghvaei , A. A., \& Rafeian, M. (2004). Estimating Rural Households' Willingness to Pay for Health Insurance. The European Journal of Health Economics, Vol. 5(3). pp. 209-215. URL: http://www.jstor.org/stable/3569979. [Accessed 08/11/17].

Abdullah, A. M., Auwal, A. G., Darham, S., \& Radam, A. (2014). Farmers' Willingness to Pay for Crop insurance in North West Selangor Integrated Agricultural Development Area. Journal of International Society for Southeast Asian Agricultural Sciences., Vol 20(2). pp 19-30. Available at: http://www.issaas.org/journal/v20/02/journal-issaas-v20n2-03-abdullah_etal.pdf [Accessed on 07/06/2018].

Abebe, H. T., \& Bogale, A. (2014). Willingness to pay for Rainfall based Insurance by Smallholder Farmers in Central Rift Valley of Ethiopia: The Case of Dugda and Mieso Woredas. Asia Pacific Journal of Energy and Environment, Vol. 1(2) pp. 121-155. Available at: http://oaji.net/articles/2014/803-1409137744.pdf [Accessed on 22/04/2018].

Berman, R. J., Quinn, C. H., \& Paavola, J. (2014). Identifying huseholds coping strategies to multiple climatic hazards in western Uganda:impilcatons for adapting to future climate change. Climate Change Development, vol.1(14) pp 1-26. http://dx.doi.org/10.108017565529.2014.902355. [Accessed 13/08/17].

Chabvungma, J., Mawenda, J., \& Kambauwa, G. (2015). Drought Conditions and Management Strategies in Malawi. In D. Tsegai \& R Adarkanian (Eds) Proceedings (series No 14) of the Regional Workshops on Capacity Development to Support National Drought Management Policies for Eastern and Sourthen Africa. UN-Water Decade Programme on Capacity Development (UNW_DPC), (pp. PP. 78-83). Bonn, Germany.

Farid, K., Tanny, N. Z., \& Sarma, P. K. (2015). Factors affecting adoption of improved farm practices by the farmers of northen Bangladesh. Journal of Bangladesh Agril. University. , Vol 13(2) pp 291-298. ISSN 18103030.

Hausman, J. (1978). Specification tests in econometrics. Econometrics, Vol. (46). pp 1251-1271.

Iheke, O. R. (2016). Analysis of factors influencing the adoption climate change mitigating measures by smallholder farmers in Imo state, Nigeria. Scientific Papers Series Management, Economic Engineering in Agriculture and Rural Development, vol 16(1) pp 1-8. ISSN 2284-7995, E-ISSN 2285-3952.

Katengeza, S. P., Holden, S. T., \& Fisher, M. (2018). Use of Integrated Soil Fertility Management Technologies in Malawi: Impact of Dry Spells Exposure. Ecological Economics, Ecological Economics Vol. 156 (2019) pp. 134-152. https://doi.org/10.1016/j.ecolecon.2018.09.018. [Accessed on 13/10/18].

Kpadonou, R. A., Owiyo, T., Barbier, B., Denton, F., Rutabingwa, F., \& Kiema, A. (2016). Advancing climatesmart-agriculture in developing drylands: Jointanalysis of the adoption of multiple on-farm soil and water conservation technologies in West African Sahel. Land Use Policy, , PP. 196-207.

Marenya, P. P., \& Barrett, C. B. (2007). Household-level determinants of adoption of improved natural resources management practices among smallholder farmers in western Kenya. Food Policy. Food Policy, Vol(32). PP. 515-536.

McFadden, D. (1978). Conditional Logit Analysis of Qualitative Choice Behavior: Frontiers of econometrics. NewYork: Academic Press. 105-142.

McIntosh, C., Sarris, A., \& Papadopoulos, F. (2013). Productivity, credit, risk, and the demand for weather index insurance in smallholder agriculture in Ethiopia. Agricultural Economics, Vol 44 (4-5) pp. 399-417. Available at http://onlinelibrary.wiley.com/enhanced/exportCitation/doi/10.1111/agec.12024 DOI: 10.1111/agec.12024 [accessed on 12/01/2016].

Montle, B. P., \& Teweldemedhin, M. Y. (2014). Assessing of the farmers' perception and economic impact of climate change in Namibia: Case study of small-scale irrigation farmers (SSIFs) of Ndonga Linena irrigation scheme. Journal of Development and Agricultural Economics, Vol 6(11). pp. 443-454. doi: 10.5897/JDAE2014.0596. [Accessed 11/06/18].

Mulwa, C., Marenya , P., Rahut, D., \& Kassie, M. (2017). Response to climate risks among smallholder farmers in Malawi: A multivariate probit assessment of the role of information, household demographics, and farm characteristics. Elsevier. http://dx.doi.org/10.1016/j.crm.2017.01.002.

Nicholson, W., \& Snyder, M. C. (2008). Micro economic theory: Basic principles and extension. 10th ed. . USA: Macmillan Publishing Co.

Omobepade, B. P., Adabayo, O. T., \& Amosi, T. T. (2014). Technical Efficiency of Aqua culturist in Etiki state, Nigeria. Oye: Federal University of Oye.

Petrine, A., \& Train, K. (2009). A Control Function Approach to Endogeneity in Consumer Choice Models. Journal of Marketing Research, Vol (46) pp. 1-45.

Phiri, I. M., \& Saka, A. R. (2008). The Impact of Changing Environmental Conditions on Vulnerable Communities in the Shire Valley, Southern Malawi. In The Future of Drylands, ed. C.S. Lee. Paris: UNESCO.

Shannon, H. D., \& Motha, R. P. (2015). Managing weather and climate risks to agriculture in North America, Central America and the Caribbean. Weather and Climate Extremes, Vol 10 pp 50-56. Available at http://creativecommons.org/licenses/by-nc-nd/4.0/. [Accessed 02/02/18]. 
Trang, N. (2013). Willingness to Pay for Area Yield Index Insurance of Rice Farmers in the Mekong Delta, Vietnam. Wageningen: Wageningen University and Research Center.

Uddin, M. N., Bokelmann, W., \& Entsminger, J. S. (2014). Factors Affecting Farmers' Adaptation Strategies to Environmental Degradation and Climate Change Effects: A Farm Level Study in Bangladesh. Journal of Climate, vol 2(10) pp 233-241. doi:10.3390/cli2040223.

us Saqib, N. (2004). Willingness to Pay for Primary Education in Rural Pakistan. The Pakistan Development Review, Vol. 43(1) pp. 27-51. URL: http://www.jstor.org/stable/41260560. [Accessed 24/10/17].

Zulu, L. (2017). Existing Research and Knowledge on Impacts of Climate Variability and Change on Agriculture and Communities in Malawi. Malawi Report No. 9. East Lansing, Michigan. Michigan: Global Center for Food Systems Innovation. gefsi.isp.msu.edu. 